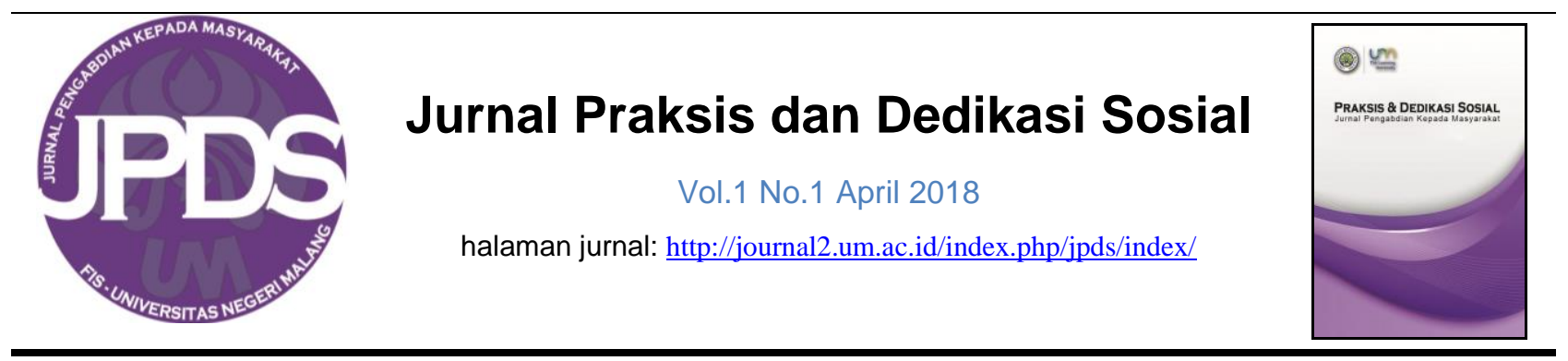

\title{
PELATIHAN PENYUSUNAN MEDIA PEMBELAJARAN SEJARAH BERBASIS MINDMAPLE PADA MATERI RELIEF CANDI JAGO BAGI GURU MGMP SEJARAH SMA SE-KABUPATEN MALANG
}

\author{
Ulfatun Nafi'ah'1, Blasius Suprapta², Daya Negri Wijaya ${ }^{3}$, Deny Yudo Wahyudi ${ }^{4}$ \\ 1,2,3,4 Jurusan Sejarah, Fakultas Ilmu Sosial, Universitas Negeri Malang. \\ Diterima 24 Maret 2018, dipublikasikan 30 April 2018.
}

\begin{abstract}
Abstrak
Pendidikan karakter dalam pembelajaran sejarah menjadi hal yang sangat penting. Kurangnya kesadaran sejarah pada peserta didik juga dipengaruhi oleh kreatifitas guru dalam mengembangkan media pembelajaran berwawasan karakter. Tujuan dari pelatihan penyusunan media pembelajaran bagi guru MGMP sejarah SMA Se-Kabupaten Malang adalah untuk memberi ketrampilan kepada guru sejarah SMA agar dapat menyusun berbagai macam media pembelajaran berbasis nilai-nilai pendidikan karakter pada materi relief candi Jago. Metode yang digunakan yiatu ceramah, pendampingan dan proyek penyusunan media pembelajaran. Hasil pelatihan penyusunan media pembelajaran berbasis MindMalpe yaitu seluruh guru dapat menyusun media pembelajaran sejarah berbasis afektif. Berdasarkan hasil evaluasi yang dilakukan maka 95\% mengatakan kegitan penyusunan media pembelajaran bermanfaat.
\end{abstract}

\section{Kata Kunci}

Pembelajaran Sejarah, Pendidikan Karakter, MindMaple, Relief.

(C) 2018 Penulis

\section{PENDAHULUAN}

Pengajaran yang baik tidak dapat disederhanakan menjadi bentuk teknik-teknik pengajaran belaka, pengajaran yang baik berasal dari identitas dan integritas gurunya (Palmer, 2009: 15). Dibutuhkan perbaikan mutu pendidikan dan teknik pembelajaran serta integritas guru untuk membentuk komunitas belajar yang bermakna, sebagai upaya dalam memperbaiki kualitas sumber daya manusia dalam menghadapi tantangan global. Salah satunya dengan memanfaatkan teknologi informasi.

\footnotetext{
${ }^{1}$ Surel korespondensi: ulfatun.nafiah.fis@um.ac.id
}

Perkembangan teknologi dan informasi saat ini sudah semakin pesat. Sayangnya kemajuan semacam ini jarang dimanfaatkan bagi pendidik untuk menunjang kegaiatan pembelajaran. Hariyono (2014) menjelaskan pada masyarakat Indonesia revolusi "Triple T" (transportasi, telekomunikasi, dan tourism) lebih dimaknai sebagai sarana kebebasan yang kurang mementingkan suatu resiko. Masyarakat larut dalam kebebasan yang cukup memprihatinkan. Kehidupan yang kini dan di sini memutus kesadaran akan waktu masa lampau sekaligus masa depan. Dewasa ini penggunaan tekhnologi secara bebas seringkali tidak diimbangi dengan tanggung 
Pelatihan Penyusunan Media Pembelajaran Sejarah Berbasis Mindmaple...

jawab, seolah-olah telah menjadi prinsip dalam masa sekarang.

Pembelajaran sejarah seringkali dianggap kering, karena hanya berbicara tentang konsep-konsep dan fakta. Hasan (TT:11-12) mengungkapkan pembelajaran sejarah telah dikerdilkan menjadi pendidikan tentang angka tahun, peristiwa, nama peristiwa, nama pelaku, dan jalannya peristiwa. Oleh sebab itu, penting kiranya memberikan bekal bagi guru sebagai pendidik untuk dapat menyusun berbagai alternatif media pembelajaran yang mudah dan dapat dikembangkan secara mandiri, agar pembelajaran sejara menjadi lebih berfariatif. Berdasarkan temuan observasi awal pada bulan November 2016 banyak permasalahan yang dihadapi oleh guru sejarah di Kabupaten Malang terkait dengan pemanfaatan dan pengembangan media pembelajaran berbasis teknologi informasi dan komunikasi dalam pembelajaran sejarah.

Pemanfaatan media dalam pembelajaran sangat penting. Degeng, I. (1989: 160) mengungkapkan bahwa media pengajaran adalah komponen strategis penyampaian yang dapat dimuati pesan yang akan disampaikan kepada si pelajar, apakah itu orang, alat atau bahan. Hal ini sejalan dengan Hamalik (1991: 12) mengemukakan bahwa media pendidikan adalah alat, metode dan teknik yang dipergunakan dalam rangka lebih mengefektifkan komunikasi dan interaksi antara guru dan siswa dalam proses pendidikan dan pengajaran di sekolah. Sedangkan Miarso dkk (1984: 48) memberikan batasan media pembelajaran sebagai segala sesuatu yang dapat digunakan untuk merangsang pikiran, perasaan, perhatian, dan kemauan siswa, sehingga dapat mendorong terjadinya proses belajar pada diri siswa. Agar dapat menjembatani pesan atau materi yang disampaikan kepada mahasiswa dapat dipahami dengan baik maka, sebaiknya guru sejarah harus mengoptimalkan pemanfaatan media pembelajaran.

Kenyataan yang dijumpai di lapangan, berdasarkan hasil observasi awal bulan Januari 2017, media yang digunakan oleh guru-guru sejarah di Kabupaten Malang hanya terbatas pada media yang sederhana seperti: pemanfaatan film dokumenter, peta, dan powerpoint. Realitanya guru sejarah seringkali dihadapkan pada kondisi siswa era digital yang segala informasi dapat dengan mudah mereka kuasai. Dari hasil evaluasi yang dilakukan pada saat pelatihan sebelumnya di tahun 2016, maka guru-guru sejarah MGMP Kabupaten Malang megharapkan agar bisa menyusun media pembelajaran sejarah secara offline, sehingga mereka dengan mudah dapat menyusun media tanpa harus terkoneksi dengan internet. Selain permasalahan tentang media, guru sejarah juga membutuhkan penyegaran materi sejarah lokal yang ada di Malang.

Berdasarkan berbagai temuan permasalahan yang ada. Maka, calon kelompok sasaran mengharapkan layanan pelatihan pengembangan media pembelajaran sejarah berbasis MindMpale dengan mater Relief Candi Jago. sebagai prioritas pertama dalam kegiatan kerjasama 
ini. Hal ini dikarenakan media ini masih belum digunakan oleh guru sejarah di Kabupaten Malang.

MindMaple merupakan salah satu software yang dapat digunakan untuk melakukan proses mind mapping. MindMaple dapat diartikan sebagai suatu software template peta pikiran untuk mengetahui bagaimana perencanaan kegiatan dapat dilakukan dengan MindMaple. MindMaple memungkinkan pengguna memulai sesuatu topik dan seterusnya menambahkan pecahan dibawahnya dengan mudah dan cepat. Berbagai jenis pilihan juga tersedia, seperti mengubah ukuran, mengubah warna, menambahkan bentuk, serta membuat kelompok topik tersendiri dan sebagainya. Pengguna juga dapat menambahkan media seperti gambar pada peta pikiran yang dihasilkan melalui MindMaple.

Pelatihan ini menggunakan program yang tidak berbayar yaitu MindMaple yang dapat diuduh secara geratis dan dapat digunakan scera offline. Harapan tersebut cukup beralasan karena berdasarkan eksplorasi awal memang menunjukkan adanya kelemahan dalam kaitannya dengan pembuatan media pembelajaran berbasis teknologi informasi dan komunikasi. Misalnya, terungkap bahwa media yang digunakan hanya sebatas melengkapi kepentingan adminitratif yang harus dikumpulkan oleh guru. Pernyataan tersebut tidak sepenuhnya salah, tetapi akan lebih baik apabila alasan tersebut bersifat akademik. Kedua, hasil telaah workshop media pembelajaran sejarah pada bulan September 2016 yang dihadiri oleh perwakilan guru sejarah dari MGMP Kabupaten Malang yang mengharapkan untuk diberi pelatihan khusus bagi guru-guru di Kabupaten Malang.

Berdasarkan analisis kebutuhan yang ada di lapangan perlu kiranya mengadakan pelatihan penyusunan media pembelajaran sejarah berbasis MindMaple untuk guru. Adapun ruang lingkup pelatihan menyusun media ini ditujukan untuk menyusun media pembelajaran sejarah berbasis MindMaple mengingat hal itu yang dibutuhkan untuk guruguru Sejarah se-kabupaten Malang. Total keseluruhan Guru Sejarah yang tergabung dalam MGMP Kabupaten Malang adalah 55 Guru. Hanya 20 guru yang mengikuti pelatihan, hal ini dilakukan agar pelatihan yang dilakukan lebih kondusif. Dari 20 guru tersebut diharapkan dapat memberikan pelatihan bagi guru sejarah lain yang tidak mengikuti pelatihan di sekolah masingmasing.

\section{METODE PELAKSANAAN}

Pelatihan ini menggunakan pendekatan andragogi, megingat bahwa kelompok sasaran adalah guru yang telah memiliki banyak pengalaman di lapangan. Walaupun mungkin terbatas, mereka telah memiliki pengalaman dalam menyusun dan memanfaatkan media pembelajaran sejarah. Metode yang digunakan dipilih untuk memenuhi variasi dengan tetap menggunakan pencapaian tujuan sebagai acuan pokok. Metode dipilih dengan memperhatikan agar kelompok sasaran menerima informasi yang diperlukan dan bersedia membuat media MindMaple secara menyenangkan. 
Pelatihan Penyusunan Media Pembelajaran Sejarah Berbasis Mindmaple...

Kegiatan ini berupa pelatihan dan pendampingan yang dikemas dalam format workshop. Setelah diberi pelatihan, tahap selanjutnya guru-guru tersebut dibimbing untuk menerapkan hasil dari pelatihan untuk meningkatkan kemampuan guru-guru dalam kegiatan membuat media pembelajaran sejarah berbasis MindMaple pada materi Relief Candi Jago. Adapun metode yang digunakan dalam pelatihan ini adalah sebagai berikut: (1) Metode ceramah, mengenai materi relief candi Jago, pentingnya pemanfaatan media dalam pembelajaran sejarah, dan bagaimana mengemas materi relief candi Jago dengan membuat peta konsep melalui program MindMaple. Materi akan disampaikan oleh tim. (2) Metode tanya-jawab mengenai media pembelajaran sejarah berbasisis MindMaple. Pada tahap ini peserta pelatihan dberikan kesempatan untuk melakukan tanya jawab dengan pemateri terkait hal-hal yang kurang dipahami dan kurang jelas. (3) Metode proyek, pada tahap ini peserta diklat diminta untuk mempraktekkan tahapan penyusunan media pembelajaran dengan materi relief Candi Jago.

\section{HASIL \\ PELATIHAN \\ PEMBELAJARAN BERBASIS MINDMAPLE}

Kegiatan pelatihan dilakukan pada tanggal 22 Maret 2017. Tim melakukan observasi awal dan melakukan koordinasi dengan MGMP Sejarah Kabupaten Malang untuk memastikan tanggal, waktu, dan tempat pelaksanaan sosialisasi. Selanjutnya, pada tanggal 22 Maret 2017 perwakilan MGMP yaitu Bapak Drs. Pi'i, M.M dan Bapak Dr. Susanto Yunus Alfian untuk melakukan koordinasi lebih lanjut. Hasilnya, rencana pelatihan akan dilaksanakan pada hari Rabu, tanggal 5 April 2017 di SMA Negeri 1 Kabupaten Malang, Jl. Mayjen Panjaitan No. 65 Sedayu, Turen, Malang. Waktu yang disediakan untuk melaksanakan kegiatan pelatihan antara pukul 08.00-13.00 WIB. Pertimbangan pemilihan waktu pelaksanaan pelatihan dan lokasi tersebut didasarkan pada hasil kesepakatan antara tim dengan kelompok sasaran yaitu guru-guru anggota MGMP Sejarah se-Kabupaten Malang. SMA Negeri 1 Turen, letaknya strategis sebagai tempat berkumpul guru-guru sejarah dari berbagai sekolah di kabupaten Malang. Selain itu, SMA Negeri 1 Turen memiliki fasilitas yang lengkap dan jaringan internet yang bagus untuk mendukung kegiatan pelatihan penyusunan media pembelajaran berbasis MindMaple.

Tim pengabdian harus berupaya mengelaborasikan materi sejarah candi Jago dan mengemasnya secara menarik. Mengingat audience terdiri dari 44 guru sejarah, sehingga sebisa mungkin materi disampaikan secara konkret, dengan bahasa yang mudah dipahami guru. Materi yang akan disajikan terkait dengan Memandang Fenomena Budaya: Relif Tantri dengan Kacamata Semiotik, dan mengemas menjadi media pembelajaran berbasis MindMaple. Tim menyajikan materi dengan artikel dan mengemas menggunakan powerpoint. Materi sejarah candi Jago sudah banyak dipahami oleh guru, sehingga tim hanya akan 
memberikan penguatan dan berdiskusi terkait penyampaian materi candi Jago yang selama ini diajarkan dan dipelajari siswa.

Keempat, tim pengabdian masyarakat perlu menyiapkan berbagai hal teknis pelaksanaan sosialisasi seperti (1) pembuatan surat tugas pada tanggal pelaksanaan atas nama tim pengabdian; (2) seminar kit yang meliputi 46 map plastik, 46 bolpoin, dan 46 handout materi; (3) 46 konsumsi acara; (4) presensi acara; (5) kamera untuk dokumentasi; (6) 46 eksemplar lembar dialog; dan (8) 46 eksemplar lembar evaluasi; (9) Banner. Dalam penyiapan hal teknis ini, tim pengabdian dibantu oleh dua mahasiswa atas nama Rike Andrias dan Santoso Ilham. Terakhir, tim pengabdian perlu juga berkoordinasi dengan mitra MGMP sejarah Kabupaten Malang untuk menata tempat pengabdian dan memasang banner. Hal lain yang diperlukan adalah pemasangan LCD, mix, sound system, serta penataan meja dan kursi.

Secara umum, kegiatan pelatihan penyusunan media pembelajaran sejarah berbasis MindMaple berjalan dengan baik. Antusiasme guru sejarah sangat bagus. Hal ini terbukti jumlah guru yang direncanakan mengikuti pelatihan hanya 20 orang. Namun, pada pelaksanaan terdapat tambahan peserta guru sejumlah 44 orang.

Acara pelatihan penyusunan media pembelajaran sejarah berbasis MindMaple dibagi menjadi III Sesi. Sesi I pelatihan berlangsung pukul 08.00 - 09.30 WIB dengan materi "Candi Jago" yang disampaikan oleh Deny Yudo Wahyudi, S.Pd., M.Hum. Beliau menyampaikan tentang kajian sejarah dan arsitektur candi Jago. Beberapa hal penting yang disampaikan diantaranya: (1) Gaya percandian berdasarkan kronologi gaya seninya, yang terdiri dari gaya klasik muda dan gaya klasik tua; (2) Gaya percandian masa majapahit yaitu kelompok gaya candi Jago, kelompok gaya Candi Brahu, dan kelompok gaya candi masa Singhasari; (3) Kelompok percandian menurut Soekmono terdiri dari gaya Jawa Tengah-an dan gaya Jawa Timur-an; (4) Sejarah Candi Jago juga disebut sebagai Candi Jajaghu, dikenal sebagai Candi Jago atau Candi Tumpang. Candi jago merupakan Pendharmaan untuk Wisnuwardhana/ Ranggawuni/ Nararya Sminingrat. Merupakan candi Buddha. Dibangun tahun $1194 \mathrm{C}$ atau $1278 \mathrm{M}$ dan pada masa Kretanagara jika mengikuti konsep Crada dan direnovasi Adityawarman gaya Majapahit; (5) Ada fenomena unik pada candi Jago, karena candi justru bernuansa SiwaBuddha. Bukti Buddha: Arca Amoghapasa dan Relief Kunjarakarna. Bukti Siwanya pada bangunan dengan gaya berundak dan (mungkin) beratap meru (tumpang); (6) Relief pada candi Jago diantaranya: Relief Tantri, Ari Darma, Arjunawiwaha, Partajayna, Kresnayana.

Setelah materi disampaikan, dilanjutkan dengan sesi tanya jawab, ada beberapa pertanyaan yang didiskusikan. Dr. Susanto Yunus Alfian, M.Pd dari SMA Negeri 1 Sumberpucung menanyakan, bagaiamana cara beribadah orang Buddha di Candi? Apakah mereka masuk ke candi atau bagaiamana? Tidak, orang Buddha beribadah 
Pelatihan Penyusunan Media Pembelajaran Sejarah Berbasis Mindmaple...

dengan cara ritual Prasawiya atau Pradaksina. Yaitu memutari candi sambil membaca mantra atau do'a. Oleh karena itu, untuk mendukung kegiatan ini maka salah satu ciri dari bangunan Buddhis adalah lantainya diperkeras.

Pada sesi II, materi disampaikan oleh Dr. Blasius Suprapta, M.Hum. Materi yang disampaikan tentang memandang fenomena budaya: relif tantri dengan kacamata semiotik. Beberapa poin penting yang disampaikan yaitu: 1) Semiotik adalah ilmu tentang tanda. Pada Abad Pertengahan Para ahli filsafat Yunani telah menyinggung pengertian dan penggunaan tanda; 2) Relief cerita tantri akan mudah dipahami jika menggunakan analisis semiotika, terutama dari Peirce; 3) Pada metode triadik terdapat tiga relasi di salamnya, diantaranya: ikon, indeks, dan simbol. Dalam kajian relief cerita tantri hanya ada dua relasi yaitu Ikon dan simbol; 4) Relief tantri di candi Jago memiliki pelajaran akan nilai-nilai kehidupan, nilai-nilai akan perbuatan; 5) Pada materi ini, dapat disusun dengan media pembelajaran yang menyenangkan, nilai-nilai yang telah teruji dan disampaikan dengan cara ceritera yakni dengan media MindMaple; 6) Hasilnya dapat digunakan untuk melakukan penelitian. Guru dapat menggunakan metode reseach dengan pendekatan semiotik. Penelitian pengembangan dengan melakukan inovasi pembelajaran sejarah.

Setelah pemateri menyampaikan informasi terkait dengan Relief Tantri candi Jago, maka tahap selanjutnya adalah sesi tanya jawab. Salah satu pertanyaan yang muncul dari Mokhammad Ismail, S.Pd yang menanyakan tentang bagaimana cara mengajarkan materi candi jago, dimana materi ini dalam kurikulum hanya mendapatkan waktu yang sangat terbatas, sedangkan pada relief candi Jago terdiri dari beberapa relief. Pemateri menjawab, cara yang dapat dilakukan oleh guru adalah dengan memberikan penugasan kepada siswa dengan strategi karyawisata. Siswa dapat diajak untuk mengunjungi candi Jago secara langsung. Pada kegiatan awal, guru dapat memberi penugasan kepada siswa. Jika jumlah siswa sangat banyak, guru dapat membagi menjadi 5 kelompok, masingmasing kelompok diminta untuk membahas tentang Relief Tantri, Ari Darma, Arjunawiwaha, Partajayna, dan Kresnayana. Guru dapat memberi lembar kegiatan siswa (LKS) agar siswa bisa fokus dalam belajar. Hasilnya dapat didiskusikan secara bersamasama. Harapannya siswa tidak hanya dapat memahami materi namun juga bisa memaknai nilai-nilai pada relief candi Jago.

Pertanyaan lain yang muncul dari Dra. Melaningrum Andarwati, bagaimana cara membedakan satu cerita relief tantri. Apa yang menjadi penanda batasan dari masingmasing cerita relief. Ada beberapa penanada, masing-masing candi memiliki ciri khas tertentu, dalam bentuk bingkai, ada dalam bentuk tiang penyangga, ada dalam bentuk tanaman (ragam hias suluran). Jika di candi Jago dibatasi dengan hiasan motif awan, dan tanaman namun bukan sulur-suluran.

Sesi terakhir pada kegiatan ini dilaksanakan pada pukul 11.00-12.00 WIB 
yaitu penyusunan media pembelajaran sejarah dengan MindMaple. Materi yang telah diulas sebelumnya menjadi bahan penyusunan media pembelajaran. Pemaparan dimulai dengan penjelasan tentang MindMaple. Mind mapping yang sering kita sebut dengan peta konsep adalah alat berpikir organisasional yang sangat hebat yang juga merupakan cara termudah untuk mendapatkan informasi ke dalam otak dan mengambil informasi itu ketika dibutuhkan.

Pemateri menanyakan kepada peserta pelatihan, apakah mereka telah memanfaatkan teknologi informasi dalam pembelajaran sejarah, sebagian besar guru telah memanfaatkan. Biasanya berupa power point, gambar dan peta digital. Namun, belum ada yang menggunakan MindMaple dalam pembelajaran sejarah. Pelaksanaan pemaparan dimulai dengan memberi beberapa penjelasan tentang kelebihan dan kekurangan MindMaple. Kelebihannya MindMaple diantaranya: 1) tampilannya familiar; 2) aplikasi MindMaple versi Lite tidak membutuhkan biaya (gratis) dan memiliki ukuran 14, $28 \mathrm{MB}$; 3) Memiliki ragam visualisasi pendukung peta konsep; 4) Terdapat fasilitas untuk menambah gambar, foto, video, link website. Selain kelebihan, tentunya MindMaple memiliki kekurangan. Adapun kekurangan MindMaple diantaranya:

1) MindMaple versi Lite (gratis) fitur yang tersedia terbatas, 2) Jika menggunakan link maka harus terkoneksi internet.

Pelaksanaan praktek penyusunan media pembelajaran sejarah berbasis MindMaple dilaksanakan pada pukul 13.00-15.00 WIB.
Pelaksanaan penyusunan media dilakukan dengan pendampingan pada kelompok kecil. Setiap guru yang hadir membawa laptop sehingga mereka dapat menyusun media secara mandiri dalam kelompok kecil. Sebelum menyusun media, guru terlebih dahulu menyusun rancangan keseluruhan point-poin yang akan disusun dalam MindMaple.

Pada penyusunan media, ada beberapa permasalahan pada saat penyusunan media, permasalahan tersebut diantaranya: 1) apakah media MindMaple dapat digunakan secara ofline?; 2) bagaimana cara mengatur tampilan media agar tersusun secara rapi?; 3) apakah tamplate hanya yang tersedia pada MindMaple atau dapat diganti dengan tamplate yang lain?; 4) bagaimana cara mengganti background?; 5) bagaimana cara menyimpan MindMaple yang telah disusun?; 6) bagaimana cara menggunakan MindMpale untuk pembelajaran sejarah?

Beberapa pertanyaan guru tersebut langsung dijawab oleh pemateri, 1) Media MindMaple dapat digunakan secara offline dengan memilih yang versi lite, hanya saja fitur yang disediakan terbatas; 2) MindMaple dapat menyesuaikan bidang kerja, jika ingin mengatur secara manual dapat dilakukan dengan meng "klik" bidang kerja dan di drag pada tempat yang dituju. 3) tamplete utama dapat dipilih sesuai ketentuan yang ada pada MindMaple. 4) untuk mengganti background dapat dilakukan dengan "klik" kanan pada mouse, pilih format background dan "klik" warna sesuai dengan yang diinginkan; 5) cara menyimpan media pembelajaran yang sudah 
Pelatihan Penyusunan Media Pembelajaran Sejarah Berbasis Mindmaple...

disusun dengan MindMaple dapat dilakukan dengan pilih menu "file" dan pilih "save", file sudah tersimpan pada folder yang ditentukan; 6) untuk memanfaatkan MindMaple, guru dapat menyimpan dalam bentuk "JPEG File" sehingga dapat digunakan juga sebagai gambar untuk powerpoint atau media lainnya, atau guru juga dapat langsung memilih format Microsoft Powerpoint Preentation agar dapat langsung digunakan dalam pembelajaran sejarah.

Guru yang mengikuti pelatihan, $80 \%$ dapat menyusun media pembelajaran secara penuh, $15 \%$ belum terselesaikan karena waktunya terbatas, dan $5 \%$ tidak mengerjakan karena laptop yang dibawa tidak dapat digunakan dengan baik, sehingga pada proses pelatihan berlangsung guru hanya menyimak kegiatan temannya. Bagi guru yang belum menyelesaikan pembelajaran dapat dikirim melalui email salah satu pemateri.

\section{Evaluasi Sosialisasi}

Pada kegaiatan berikutnya dilakukan evaluasi secara menyeluruh terkait pelaksanaan pelatihan media pembelajaran berbasis MindMaple. Penilaian atau evaluasi kegiatan seringkali dipahami sebagai cara untuk mengukur atau memeriksa ketercapaian kompetensi pengetahuan, sikap, dan keterampilan peserta kegiatan. Menurut Arifin (2009:4), evaluasi atau penilaian merupakan proses yang sistematis dan berkesinambungan untuk mengumpulkan informasi tentang proses keberlangsungan kegiatan. Lebih lanjut menurutnya, evaluasi dapat digunakan untuk mengetahui keefektifan kegiatan pengabdian pada masyarakat. Hasil yang diperoleh dapat dijadikan sebagai balikan bagi tim pengabdian untuk memperbaiki dan menyempurnakan program dan kegiatan pengabdian.

Tim pengabdian melakukan refleksi internal sehari setelah kegiatan selesai. Tim merasa bahwa (1) perlu melakukan persiapan yang panjang, terutama pada persiapan materi, perlu dilakukan agar kegiatan yang dilakukan berjalan dengan lancar dan sukses. Termasuk bahasa yang digunakan dalam menyampaikan materi kepada guru. Oleh sebab itu, perlu dilakukan simulasi sebelum kegiatan pengabdian berlangsung.; (2) tim pengabdian perlu mengantisipasi berbagai hambatan yang mungkin akan menjadi penghalang kegiatan pengabdian. Kegiatan ini, bersamaan dengan aktivitas lain seperti pemateri Daya Negri Wijaya, M.A harus menjadi pemateri dalam kegiatan PPG. Dr. Blasius Suprapta, M.Hum harus menguji skripsi sehingga tidak dapat mengikuti kegiatan pengabdian secara penuh. Guru yang harusnya datang tepat waktu, karena jarak rumah dengan lokasi pengabdian cukup jauh maka ada beberapa guru yang datang terlambat; (3) pelaksanaan kegiatan setidaknya perlu dibantu oleh tiga orang yang berfokus untuk mengurusi hal teknis. Hal ini berguna untuk meminimalisirkan tugas-tugas ganda pelaksana pengabdian seperti salah satu anggota yang bukan hanya berperan sebagai sekretariatan atau penerima tamu tetapi juga sebagai Master of Ceremony (MC); (4) perlu seseorang yang secara khusus menjadi notulen pelakasanaan pelatihan, dan 
perlu ada perekaman kegiatan dari awal sampai akhir agar mempermudah dalam penyusunan laporan pengabidan (5) tim pengabdian merasa bahwa materi yang disampaikan cukup mengena. Hal ini terlihat dari respon yang diberikan oleh guru, banyak pertanyaan yang didiskusikan selama proses berlangsung, dan setiap guru juga menyusun media dengan baik.

Selain melakukan refleksi, tim juga melakukan evaluasi. Evaluasi dilakukan oleh peserta pelatihan. Respon peserta kegiatan dapat dilihat dari angket yang telah diberikan. Mereka melihat bahwa empat materi yang diberikan secara umum sangat bermanfaat dan menarik. Adapun secara detail, materi relief cerita tantri di candi Jago sangat bermanfaat (55\%); hal yang bermanfaat (39\%); dan hal yang cukup bermanfaat (6\%). Menurut mereka, penyajian materinya dirasa sangat menarik (52\%); menarik (42\%); dan cukup menarik (6\%). Sedangkan pada materi kedua, tentang kajian Candi Jago mereka merespon materi sebagai hal yang sangat bermanfaat (74\%); hal yang bermanfaat (26\%); Selain itu, mereka juga melihat bahwa penyajian materi kedua dirasa sangat menarik $(68 \%)$; menarik (32\%). Selain evaluasi untuk materi ke 1 dan ke 2, maka sajian materi yang ke 3 dirasa sangat bermanfaat (74\%), bermanfaat $(23 \%)$ dan cukup bermanfaat (3\%). Adapun kemenarikan penyajian penyusunan media pembelajaran sejarah berbasis media MindMaple sangat menarik (46\%), menarik (48\%), dan cukup menarik (6\%).
Lebih lanjut, mereka ternyata juga memberikan berbagai komentar dan saran terkait dengan penyelenggaraan pelatihan media pembelajaran sejarah berbasis MindMaple ini. Beberapa intisari komentar yang diberikan, meliputi: 1) Penyelenggaraan pelatihan semacam ini lebih sering diadakan untuk guru agar pembelajaran sejarah lebih bervariatif. Harapannya kegiatan dan kerjasama dengan tim MGMP Sejarah dan antropologi terus berlanjut; 2) Pelatihan penyusunan media pembelajaran sangat menarik serta memberikan referensi baru dalam pembuatan media untuk kegiatan belajar mengajar khususnya matapelajaran sejarah; 3) Sangat bermanfaat dan menarik, semoga dapat dipraktekkan di dalam kelas; 4) Penyajian media sangat menarik dan perlu dikembangkan dengan menggunakan materi yang lain. 5) Pelatihan penyusunan media pembelajaran cukup menarik, dapat wawasan baru tentang media pembelajaran yang interaktif dan sangat bermanfaat.

Akan tetapi, mereka juga memberikan berbagai saran yang bersifat konstruktif, seperti: 1) Waktu yang digunakan terlalu singkat, dan banyak materi yang disampaikan. Sehingga, tidak dapat menyelesaikan media dengan maksimal; 2) Perlu memilih waktu pelaksanaan yang tepat, agar tidak bersamaan dengan kegiatan ujian; 3) Harus ada pendampingan yang lebih detail kepada guru, karena guru tidak dapat menyelesaikan dengan cepat seperti yang diistruksikan pemateri; 4) Perlu diadakan workshop lain tentang penelitian, penulisan jurnal, dan penulisan artikel untuk jurnal atau paper 
Pelatihan Penyusunan Media Pembelajaran Sejarah Berbasis Mindmaple...

seminar nasional; 5) Diharapkan dapat membawa contoh-contoh jurnal; 6) Perlu dikembangkan media pembelajaran yang lain; 6) Penataan ruang dapat dibuat melingkar agar pelatihan bisa lebih kondusif dan komunikatif 7) Mohon ada keberlanjutan pendampingan di kelas, agar ada kolaborasi antara guru dan dosen dalam memberikan pelayanan kepada siswa.

\section{KESIMPULAN}

Kegiatan "Pelatihan Penyusunan Media Pembelajaran Sejarah Berbasis Mindmaple pada Materi Relief Candi Jago Bagi Guru MGMP Sejarah Kabupatan Malang" secara umum dapat terlaksana dengan baik. Hal ini terlihat dari kelancaran kegiatan walaupun ada beberapa peserta yang berhalangan hadir. Peserta sangat antusias untuk mengikuti pelatihan dari awal hingga akhir kegiatan. Melalui diskusi, peserta dapat menemukan cara untuk memaknai sejarah dari materi lokal candi Jago. Selanjutnya, guru dapat menyusun media pembelajaran sejarah dengan MindMaple dan dapat diterapkan di kelas. Hasilnya, terdapat tiga orang guru yang mengirimkan hasilnya menjadi makalah dan diikutkan pada kegiatan seminar nasional jurusan sejarah. Peserta pelatihan merasakan manfaat yang luar biasa, mereka dapat menyusun media pembelajaran sejarah yang lebih variatif dan inovatif. Setelah pelaksaan pelatihan, guru tetap melakukan komunikasi dengan tim pengabdian untuk menindaklanjuti kegiatan pengabdian.

\section{DAFTAR RUJUKAN}

Arifin, Z. 2009. Evaluasi Pembelajaran: Prinsip, Teknik, \& Prosedur. Bandung: PT Remaja Rosdakarya.

Degeng, I. 1989. IImu Pengajaran: Taksonomi Variable. Jakarta: Depdikbud. Dirjen Dikti: P2LPTK.

Hariyono. 2014. Kekuasaan dalam Proses Pembelajaran Sejarah: Membangun Kuasa Diri. Makalah disajikan dalam Seminar Nasional Pembelajaran Sejarah di Tengah Perubahan, Jurusan Sejarah Universitas Negeri Malang. Malang, 27-28 September.

Hamalik, O. 2011. Strategi Belajar Mengajar. Bandung: Mandar Maju.

Hasan, Hamid. Problematika Pembelajaran

Sejarah. (Online

(http://file.upi.edu/Direktori/FPIPS/JUR. P

END. SEJARAH/194403101967101-

SAID HAMID HASAN/Makalah/Beberap

a Problematik Dalam Pendidikan Sejar

ah.pdf) diakses tanggal 6 Agustus 2016.

Miarso, Yusufhadi. 2011. Menyemai Benih

Teknologi Pendidikan. Jakarta: Prenada Media.

Palmer, P.J. 2009. Keberanian Mengajar, Menjelajah Ruang Nurani Kehidupan Guru. Jakarta: Indeks.

http://www.MindMaple.com 